\title{
Beyond iPS!
}

It's undoubtedly a jubilant moment for scientists and clinicians working in the stem cell arena as Prof. Gurdon and Prof. Shinya Yamanaka have been chosen for the Nobel Prize in Physiology \& Medicine this year.

The mystery of cell biology is something unfathomable and probably the work of this duo as well as the other scientists, who have put their hands on in- vitro de-differentiation have opened our eyes to a new window or a new paradigm in cell biology. The iPS invention has brought a lot of hope in terms of potential direct benefits to treat several diseases, which have no definite options at the moment. But, we envisage that several spin-offs could come out of this invention and one very significant spin-off finding recently witnessed is the finding by Prof. Masaharu Seno and his team of researchers at the Okayama University, Japan (Chen L, et al. 2012, PLoS ONE 7(4):e33544.doi:10.1371/journal.pone.0033544).

According to Prof. Seno, mouse iPS cells (miPS) when cultured in the conditioned medium derived from cancer cell lines, differentiate into cancer stem cells (CSCS). While differentiating into CSCS, they do retain the potential to develop endothelial progenitor cells.

Several questions arise here:

Are these miPS derived CSCs really pluripotent, even if the terminal differentiation destined to specific phenotypes?

Shouldn't the Cancer Stem Cells be termed as cancer progenitor cells, as till date they are considered to be producing only cancer cells but not pluripotent to yield other types of normal tissues?
The spin-offs could be infinite as the process of differentiation and de-differentiation happening due to trillions of signals and pathways, most still remaining notso-well understood

A special mention should be made to Prof. Shinya Yamanaka as he has several sterling qualities to be a rolemodel for budding scientists. Apart from his passion for science, which made him shift his career from orthopedics to a cell biologist, his open acknowledgement that he chose a research career as he was not good in surgical procedures, is something that teaches us to keep going ahead even when we know our limitations. Another important quality we appreciate in him is his team-spirit and perseverance. Not only as a member of the university Judo team, but after starting the iPS research when sourcing research funds was difficult, he plunged into organizing a marathon run, which he completed till the finish line is a marvelous feat to showcase his perseverance.

As this issue is published with articles on molecular profiling of human breast cancer initiating cells, allogeneic amniotic membrane-derived mesenchymal stromal cell (AMSC) transplantation and mononuclear stem cell therapy, we look back, recognize and salute the genius of Alexander Maximov, who coined the term "Stem Cell" in 1908, Joseph Altman \& Gopal D.Das who reported the post-natal neurogenesis in the 1960s and James E.Till \& Ernest McCulloch, who discovered the presence of self-renewing cells in bone-marrow in 1963 that later led to the bonemarrow transplantation as a treatment.

“...But they, while their companions slept, were toiling upward in the night."

- Henry Wadsworth Longfellow 